\title{
All Counterinsurgency is Local: Counterinsurgency and Rebel Legitimacy
}

\section{Andrew J. Gawthorpe}

To cite this article: Andrew J. Gawthorpe (2017) All Counterinsurgency is Local:

Counterinsurgency and Rebel Legitimacy, Small Wars \& Insurgencies, 28:4-5, 839-852, DOI:

10.1080/09592318.2017.1322330

To link to this article: https://doi.org/10.1080/09592318.2017.1322330
(c) 2017 The Author(s). Published by Informa UK Limited, trading as Taylor \& Francis Group
曲 Published online: 26 Jul 2017.

Submit your article to this journal $\pi$

Џلll Article views: 616

Q View related articles $\Longleftarrow$

View Crossmark data $\nearrow$ 


\title{
All Counterinsurgency is Local: Counterinsurgency and Rebel Legitimacy
}

\author{
Andrew J. Gawthorpe \\ Institute for History, Leiden University, Leiden, The Netherlands
}

\begin{abstract}
Although the concept of legitimacy is central to Western counterinsurgency theory, most discourse in this area black-boxes the concept. It hence remains under-specified in many discussions of counterinsurgency. Fortunately, recent research on rebel governance and legitimacy contributes to our understanding of the problems faced by counterinsurgents who want to boost state legitimacy while undermining that of the rebels. Taken together, this research illustrates that a rational choice approach to legitimacy is simplistic; that micro-level factors ultimately drive legitimacy dynamics; and that both cooption of existing legitimate local elites and their replacement from the top-down is unlikely to succeed. Western counterinsurgency doctrine has failed to grasp the difficulties this poses for it.
\end{abstract}

ARTICLE HISTORY Received 25 October 2016; Accepted 20 March 2017

KEYWORDS Rebel government; legitimacy; counterinsurgency; nation-building

Although the idea of contesting it is central to Western counterinsurgency, legitimacy remains under-explored in much literature on the topic. This lacuna is unfortunate given the importance which both theorists and practitioners of counterinsurgency warfare ascribe to the contest for legitimacy between insurgents and counterinsurgents. Fortunately, recent scholarship on rebel governments - including that represented in this special issue - sheds light on the sources, resilience and decay of rebel legitimacy. This paper aims to serve as a starting point for a discussion of the links between counterinsurgency and rebel legitimacy by exploring how recent work in the latter field sheds new light on the theory and practice of counterinsurgency.

\section{CONTACT Andrew J. Gawthorpe a.j.gawthorpe@hum.leidenuniv.nl}




\section{Rebel legitimacy and counterinsurgency}

The concept of legitimacy is central to Western writing on counterinsurgency. US capstone military doctrine places counterinsurgency in the category of 'irregular warfare', which it defines as'a violent struggle among state and non-state actors for legitimacy and influence over the relevant population(s).' In it revised 2014 edition, US counterinsurgency doctrine states that'[l] egitimacy, the acceptance of an authority by a society, and control are the central issues in insurgencies and counterinsurgencies'. It also presents the pursuit of legitimacy as a key differentiating factor between counterinsurgency and regular warfighting, as in counterinsurgency'[a]chieving success may depend less on defeating the armed element of the insurgency and more on the ability to legitimize host-nation institutions to the populace.'. The same message can be found in NATO and other allied doctrine. ${ }^{3}$

Doctrine-writers have also been clear that counterinsurgency involves not just an attempt to bolster the legitimacy of an incumbent state, but that it is fundamentally a struggle between competing legitimacies. Insurgents also seek to develop their own legitimacy, and the successful counterinsurgent must stop them. 'The insurgency will attack the legitimacy of the host-nation government while attempting to develop its own credibility with the population, notes FM 3-24. 'The host-nation government should reduce the credibility of the insurgency while strengthening its own legitimacy'. Unless an insurgency is prevented from providing 'effective governance', it may 'build local legitimacy', increasing the potency of its threat to the incumbent state. ${ }^{4}$ In Western writing on counterinsurgency, the struggle between the insurgent and counterinsurgent to establish their legitimacy in the eyes of the population hence emerges as the key site of struggle.

Despite this, there has been surprisingly little critical reflection on the concept of legitimacy - and especially rebel legitimacy - among Western counterinsurgency theorists. This lacuna can be traced back to the counterinsurgency writers of the classical era of the 1960s whose pedigree today's theorists often claim. The concept of legitimacy is almost entirely absent from the writings of David Galula. Although his classic text Counterinsurgency Warfare notes that incumbent governments hold 'legitimate power' at the start of a conflict, he does nothing to probe the meaning of this concept or to consider the struggle for legitimacy between the government and rebels. ${ }^{5}$ Neither the word 'legitimacy'nor any of its cognates appear once in Roger Trinquier's Modern Warfare, another classic text. ${ }^{6}$ Instead, the classic writers relied on the concept of 'support'. Theorizing that most of the population in a country undergoing an insurgency were essentially apolitical or attentiste (fence-sitters), they saw insurgents and counterinsurgents as waging an active struggle to control and mobilize the population. The resultant 'support' that accrued to the group most able to do so was, according to Galula, explicitly not a matter of an ideational judgement 
about legitimacy but was 'dictated ... by the more primitive concern for safety'. He added: 'Which side gives the best protection, which one threatens the most, which one is likely to win, these are the criteria governing the population's stand.' The upshot of this was that counterinsurgents needed to develop coercive structures of control which mirrored the insurgents' organization in order to shape popular preferences. ${ }^{8}$ Legitimacy in the sense of an ideational commitment felt by a population towards a particular system of governance was hence less important than the manipulation of behavior through essentially coercive state practices.

Today's Western counterinsurgents are less keen to so openly identify their cause with coercive practices, a fact reflected in the key place occupied by 'legitimacy' in contemporary theory. This demands in turn a focus on ideational factors and popular preferences as opposed to mere behavior. FM 3-24 and its derivatives take a constructivist approach to the matter, espousing the view that identity can be manipulated and an ideational commitment to a particular governance structure can in effect be created through effective social engineering. ${ }^{9}$ But the same writings lack any sophisticated understanding of what legitimacy is or the ways in which it emerges, endures and dies. They are unable to draw on their classical forebears for insight because the concept was absent from their writings, and nor have they engaged with the emerging social science literature which could help them understand insurgent and incumbent legitimacy better. Instead, the technicians of counterinsurgency have black-boxed a key concept upon which their claim to be able to deliver victory rests.

Recent research has juxtaposed the Western model of counterinsurgency with an 'authoritarian model.' ${ }^{10}$ Rather than focusing on legitimacy, authoritarian counterinsurgents are held to rely much more heavily on all the myriad tools of coercion at their disposal: murder, torture, incarceration, forced resettlement, ethnic cleansing, heavy intelligence penetration and societal control. Some writers have even identified the refusal of democracies to 'escalate the level of violence and brutality to that which can secure victory' as the reason why, in comparison to authoritarian states, they are 'inclined to fail in protracted small wars.'11 Yet, as Ucko has pointed out, this distinction between authoritarian and Western counterinsurgency may be overblown. Although authoritarian actors show a much greater willingness to use coercion in pursuit of their goals, these goals do not differ markedly from those sought by Western counterinsurgents. Both are ultimately concerned with 'sustaining domestic support, separating insurgents from the population, and spreading state control'. The achievement of these goals can never be purely a function of violence and surveillance, which occur within a broader political and societal context. ${ }^{12}$ Like their democratic counterparts, authoritarian counterinsurgents seek to manipulate this context using a mixture of violent and non-violent means to reach their goals. A reliance on mass slaughter alone may be appropriate for génocidaires, but not for 
counterinsurgents who ultimately aspire to govern their target population. As Arendt writes, 'nobody can rule over dead men' ${ }^{13}$

Just as all counterinsurgents deploy some measure of coercion - and Western counterinsurgents have done so much more often in practice than in theory so they all must also concern themselves with legitimacy. As Duyvesteyn discusses in the introduction to this special issue, understandings of legitimacy can broadly be either normative or descriptive. Normative discussions are about the moral justifiability of legitimacy claims, while descriptive understandings reflect rather on whether the relevant actors consider authority to be legitimate or not. This article follows in the descriptive tradition, seeing legitimacy as 'a descriptive concept about normative judgements, but ... not itself a normative concept. ${ }^{\prime 4}$ Research in this tradition has been replete with insights which open up the black box of legitimacy and the process of legitimation. In turn, this allows us to explore in more detail the difficulties faced by counterinsurgents who attempt to degrade the legitimacy of rebel groups and legitimate their own. This paper now turns to consider some of those difficulties.

\section{Primacy of the local}

As numerous scholars of irregular warfare have observed, it has a 'tremendous capacity to segment space.' ${ }^{\prime 5}$ The political authority and military control of rival sides often spread in a crazy-quilt patchwork over territory. One village might be in the hands of the insurgents while its neighbor is controlled by the government. Furthermore, it might be unclear or ambiguous exactly which side controls an area, even to the combatants themselves. The cliché of a'war without fronts' captures this idea well. Such is the confusion which ensues that counterinsurgents have often felt forced to use complicated statistical tools to try to analyze territorial control, such as the famed Hamlet Evaluation System in the Vietnam War. An obsession with quantifiable data points led the US military to focus heavily on enemy body count and kill/capture ratios, a measure that provided almost zero insight into territorial control. In this conflict as in many others, an understanding of the true reach of insurgent organization and control eluded American commanders. ${ }^{16}$

Counterinsurgents find it difficult to measure the dynamics of political and military control because it rests in part on the elusive concept of legitimacy. ‘Political legitimacy of a government determines the degree to which the population will voluntarily or passively comply with the decisions and rules issued by a governing authority,' notes FM 3-24.'Legitimacy determines the transaction costs of political and governmental power. ${ }^{17}$ Building on Dahl's classic analysis of how coercive power seeks to 'clothe itself in the garments of legitimacy', scholars of rebel government have argued that legitimation does indeed reduce the transaction costs of governance by promoting voluntary cooperation. ${ }^{18}$ But the relative legitimacy enjoyed by both sides in any given village or province is 
impossible to establish, a frustration shared by both scholars and counterinsurgents. The usual metrics used to measure progress in counterinsurgency - such as the number of enemy-initiated attacks or the number of civilians willing to volunteer information on the movement of insurgents - give at best partial insight into the question. Because legitimacy is rooted in the preferences and attitudes of the population, there are few physical or quantifiable data points which can be used to measure it. Understood as a determinant of the transaction costs of governing, the extent of legitimacy enjoyed by a government or rebel group can only be understood by observing the population's responses to their concrete actions. Until then, like Schrödinger's cat, the status of legitimacy is unknown.

The segmentation of physical space which accompanies irregular warfare is accompanied by a parallel segmentation of social, political, and economic space. This also leads to a segmentation of legitimacy dynamics, as scholars focusing on the micro-level of war have stressed. ${ }^{19}$ This renders problematic the understanding of legitimacy offered in Western counterinsurgency doctrine. The revised FM 3-24 notes that legitimacy is 'the acceptance of an authority by a society.' The population of a particular society determines who has legitimacy to establish the rules and the government for that society', it continues. 'A population's values and cultural norms will determine who that society perceives as a legitimate authority.20 But this analysis ignores the fact that the social fragmentation which takes place in many irregular wars means that counterinsurgents are typically dealing with hundreds if not thousands of micro-societies with their own histories, norms, and expectations bearing on legitimacy. In countries with weak central states, this fragmentation of governance likely predates the conflict, with a reliance on local, traditional and customary authority prevalent and the incumbent state seen as a distant, alien, and illegitimate institution.

The cliché that all politics is local is hence likely to hold true in countries beset by irregular warfare, and especially in the weak states which Western counterinsurgency doctrine has been designed to buttress. This means that the struggle for legitimacy has to be conducted at the local level. Counterinsurgency calls for incumbent political power to be legitimized - and for that of the insurgency to be undermined. In situations of dispersed and fragmented legitimacy, this either means that one concept of legitimacy must be imposed from the top down or that a patchwork of legitimacies must be built from the ground up. Both approaches present problems

\section{From the top-down}

Scott's work on state attempts to impose 'legibility' on societies from the top down has suggested that grandiose state-driven attempts at social engineering usually fail. By demonstrating the resilience of organic local norms in the face of coercive attempts to rationalize society by the state, Scott leads us to expect 
that attempts to replace the heterogeneous forms that legitimacy takes with one unified concept focused on the state will be unsuccessful. ${ }^{21}$

Attempts to claim otherwise have often been based on simplistic and fallacious historical analogies. For instance the writers of the FM 3-24 argued that '[s] unification of Germany in 1871, [can] create a change in group identity and accepted authority.22 Yet this drastically overstates the extent to which such changes took place as a result of these events. In the case of American independence, there was widespread and enduring disagreement over the form that 'accepted authority' should take, culminating in the Civil War. On the other hand, the 1871 unification of Germany was only one event in a centuries-long process of emerging German nationalism. ${ }^{23}$ For other European nation-states the paradigm on which much of the democratic approach to counterinsurgency is based - the development of a monopoly on the legitimate use of violence by the central state also took centuries. ${ }^{24}$ Weak post-colonial states whose borders do not correspondent to any pre-colonial political community face even steeper challenges in usurping local legitimacies.

Unsurprisingly, research on the micro-level of legitimacy has indeed shown that local legitimacies are bound up with local traditions, customs, norms, social structures and economies from which they developed more or less organically. Although war may disrupt these factors, they still remain the baseline against which legitimacy is understood locally. This presents a challenge to both Western counterinsurgents attempting to spread liberal norms based around the central state and to more coercive counterinsurgents who attempt to develop new identities through forced resettlement and re-education. State attempts to impose a new norm of legitimacy from the top down can be resisted and subverted in myriad ways from the bottom up. ${ }^{25}$

The characteristics of an insurgency also affects the difficulties which counterinsurgents will face in attempting to degrade rebel legitimacy and supplant it with their own from the top down. Western counterinsurgents have frequently depicted their enemies as atomized 'bandits' who are understood as mere criminals with no legitimacy in the eyes of the broader population. More subtly, the modernization discourse which lay behind cold war counterinsurgency and which is still influential today sees insurgents as delinquents led astray by mismanagement of the modernization process. As Rostow said, Communist insurgencies were a 'disease of the transition to modernization'.26 Both of these simplistic views ignore the extent to which rebel groups are often embedded in long-standing local political, social and economic systems and subcultures of resistance to state authority. Such groups are likely to enjoy substantial legitimacy.

To understand how differences between insurgencies and their legitimacy complicates counterinsurgency, it is useful to consider Weinstein's distinction between 'opportunist' and 'activist' rebellions. Opportunist rebellions are those 
able to easily acquire resources without the consent of the civilian population, whereas activist rebellions rely on civilian consent to mobilize. This leads to variation in behavior, with activist rebels seeking to strike cooperative bargains with civilians and to develop their legitimacy in the eyes of the population. Such rebellions tend to attract individuals who have ties to the local population and share their norms of behavior. Opportunist rebels, on the other hand, attract individuals motivated by the prospect of short-term gain. ${ }^{27}$ While opportunist rebels approximate the idea of a'bandit' which has been so prevalent in Western counterinsurgency discourse, activist rebels enjoy a deep legitimacy which this discourse has never adequately addressed. The support of local populations makes activist rebellions extraordinarily resilient. Especially in countries in which the central state has never been strong, activist rebels build on pre-existing norms and political structures to establish their legitimacy. ${ }^{28}$ These norms often include a strong tradition of resistance to the central state. Rather than being criminals or delinquents, activist rebels are an organic outgrowth of the societies or micro-societies from which they spring. Activist rebellions are particularly likely to enjoy legitimacy which has the characteristics that Duyvesteyn analyzes in the introduction to this special issue. Firstly, because they recruit individuals locally based on shared norms, they can claim an overlap with pre-existing social and political rules in their locality. Secondly, the beliefs by which these rules are viewed as legitimate are shared both by rebels and civilians. Thirdly, because they go to great lengths to strike and maintain cooperative bargains with civilians, these rules are likely to be reflected in practices demonstrating compliance.

Democratic counterinsurgency finds such rebellions extremely difficult to deal with. FM 3-24 is somewhat schizophrenic on the subject of what ought to be done with them. While it stresses that legitimacy must be understood in local terms, it also suggests that the only acceptable end-point is 'security under the rule of law'. The deployment of law enforcement assets to tamp down rebellions will lead to them being 'seen as criminals', meaning they will 'lose public support.29 ${ }^{29}$ The idea that the solution to rebellions is an essentially apolitical 'rule of law' embodies a norm which is unlikely to be shared by populations supporting activist rebels. It is infrequent that counterinsurgents possess the understanding of the norms of a distant population which they would require to adapt their approach accordingly, especially given the urban bias of most incumbent governments. Even if they did possess this knowledge, they could be unable to overcome the fact that legitimacy is often based more on the identity of those providing governance rather than their actions. Sectional, geographic and ethnic splits may prevent local populations from ever accepting the servants of the central state as legitimate rulers, while causing them to continue to support activist rebels who share their identity. Meanwhile, Western militaries intervening in support of an incumbent host government face these problems in magnified form. Their understanding of the basic features of the social, political 
and economic terrain of the country in which they are intervening is likely to be minimal, and what understanding they do develop is likely to reflect the urban bias of the host government. The tendency to view insurgents as apolitical bandits discourages an understanding of the way that a sharing of norms between them and local populations sustains insurgent legitimacy. Meanwhile, as foreigners who can become the target of nationalist mobilization, their identity is an even greater barrier to ever being identified as a legitimate partner of the host government in establishing its own legitimacy.

Authoritarian counterinsurgents likewise find activist rebellions who enjoy strong legitimacy difficult to deal with. As Valentino, Huth and Balch-Lindsay have argued, mass indiscriminate coercion is particularly likely to be employed against insurgencies which enjoy strong legitimacy and share an identity with civilians, thus making it harder to separate the insurgents from the population. ${ }^{30}$ Perhaps the most potent effect of a broad coercive program is in undermining the smooth functioning of rebel governance by denying the rebels the ability to provide stability and predictability to civilians under their rule. This can undermine rebel legitimacy, especially if they are blamed for provoking the state into violent acts. ${ }^{31}$ But recent research has suggested the limits of mass indiscriminate coercion as a tool in degrading rebel legitimacy. While'bandits' might have a purely instrumental relationship with the population, activist rebels enjoy a broader relationship which is more difficult to sever. Despite the disruption to rebel governance, high-commitment rebels are likely to seek to evade the violence by temporarily relocating to more remote areas. Meanwhile, in a pattern famously observed by Scott, individuals or groups who view the state as legitimate are likewise to flee indiscriminate violence by heading to centers of state authority, such as towns or major communication routes. ${ }^{32}$ The result is a more polarized countryside in which rebels are able to increase their legitimacy among those civilians who remain by providing protection from indiscriminate violence and capitalizing on the symbolic pose of resistance. ${ }^{33}$

In situations of extremely effective or prolonged campaigns of coercion, rebels may eventually be forced to adopt a more instrumental and coercive stance towards the civilian population in order to extract the resources they need to continue functioning. Weinstein has noted that rebels who make this transition from being activists to opportunists rarely manage to transition back. ${ }^{34}$ Yet even if rebels are forced to sacrifice some legitimacy in absolute terms in the face of mass indiscriminate coercion, this in no way guarantees that their legitimacy relative to the counterinsurgent also lessens. While such coercion might disrupt and degrade rebel legitimacy, the impact of violence and its tendency to depopulate the countryside of pro-government elements creates an inauspicious terrain for the government to erect a long-term political solution. An example of this dynamic can be seen in the Vietnam War. The rural population and the National Liberation Front (NLF) suffered an enormous quantity of indiscriminate violence which depopulated the countryside and 
led the NLF to establish a more coercive relationship with the population. Yet even though their own legitimacy was degraded, the government never managed to supplant rebel governance with their own legitimate apparatus, or to reduce NLF legitimacy to the point where the organization was forced to cease functioning. Each time the violence stopped, the NLF was able to reestablish the bare amount of legitimacy and ability to function to allow it to continue to harass the government. ${ }^{35}$

\section{From the ground up}

Rather than attempting to degrade and supplant rebel legitimacy from the top down, counterinsurgents can attempt to build a patchwork of legitimacy from the ground up. This means attempting to coopt local rebel legitimacies through a bargain which allows state and local elites to reach a political settlement. Instead of pursuing the quixotic project of spreading one unified norm of legitimacy, this allows the regime to capitalize on pre-existing legitimacies enjoyed by rebels among the population. The most famous recent example of this policy was the 'Sunni Awakening' during the US war in Iraq. Frustrated by their efforts to directly spread the reach and legitimacy of the Baghdad regime, the US instead reached out to Sunni rebel leaders themselves. By providing support and resources to one segment of the rebel elite, the US was able to capitalize on their local legitimacy to turn the tide against Al-Qaeda in Iraq. Often considered as a high water mark in recent US counterinsurgency, the policy directly contradicted FM 3-24's insistence that the establishment of state legitimacy is the central issue. Instead, it represented a retreat from this point and an acknowledgement that legitimacy often depends as much on who governs as how they govern. The legitimacy of Sunni rebels was based on their shared norms and identity with the local population, something the Shia government in Baghdad could not hope to supplant without coopting them. ${ }^{36}$

Yet this manner of dealing with rebel legitimacy brings problems of its own. Once again, research into rebel governance gives insight into how variation in the characteristics of insurgencies will affect the suitability of this approach. In particular, research on how the identity of rebel movements is instantiated in their approach to governance has revealed a wide divergence in their goals. Arjona's typology of rebel governments as either 'rebelocracy' or 'aliocracy' is a source of particular insight. A rebelocracy is a rebel government whose goals extend beyond the instrumental, establishing a broader relationship with society and delivering reforms to pre-existing local governance. By contrast, an aliocracy ('rule by others') is content to leave pre-existing local governance structures in place while seeking only the freedom to operate and extract resources. ${ }^{37}$ By seeking comprehensive reforms which aim to overthrow the status quo, rebelocracies are more likely to have goals that are ultimately incompatible with those of the central state. As a result, attempts to coopt their legitimacy 
are problematic because this very legitimacy depends on the extent to which they oppose the order and legitimacy represented by the central state and its local allies. Furthermore, Kalyvas has found a strong link between the amount of territorial control enjoyed by a rebel movement and form of government it establishes, with strong control correlated with a more interventionist and ideological form of governance. ${ }^{38}$ As a result, any political settlement reached between the state and rebel elites which strengthens the hand of the latter is likely to only further entrench the political divisions which spurred the conflict to begin with. Because conflicting legitimacies is precisely what is at issue in counterinsurgency, such arrangements are hence unlikely to be stable in the long term - exactly as the uneasy peace between Baghdad and its Sunni population eventually unraveled.

\section{Conclusion}

Research into rebel legitimacy poses a stark challenge to counterinsurgency discourse, and especially FM 3-24 and its derivatives. Not only does this discourse not problematize the concepts of legitimacy or legitimation, but it seems to call for actions which have little hope of achieving its architects' goal of besting rebels in a battle to build and sustain legitimacy. This article raises at least three critiques of counterinsurgency discourse.

Firstly, the rational choice approach to civilian agency in warfare which underlines FM 3-24 and its derivatives needs revising. In this view - long a feature of Western counterinsurgency discourse - legitimation is seen as occurring through a process in which civilians give the blessing of legitimacy to the actor they feel provides them with the best 'package' of governance. Governance hence becomes something of an open market in which each actor attempts to provide the best product to civilians in exchange for the blessing of legitimacy. ${ }^{39}$ Yet - to continue the analogy - the market for governance is not at all free or open. Instead of civilians making 'rational' choices as market participants, legitimation is a culturally-bounded process that unfolds according to local norms. The barriers to entry for outsiders into this market are extremely high, given their lack of information, association with an alien and often predatory outside state, and lack of shared norms or identity with the population they are trying to win over. By contrast, many rebels possess just the qualities needed to establish a monopoly.

Secondly, theorists must recognize that all counterinsurgency is local. While doctrine-writers and theorists naturally seek to provide generalizations applicable to as wide a variety of local and micro-situations as possible, they still have to confront the problems caused by the fragmentation of space, governance, and legitimacy which invariably accompanies irregular warfare. In such situations, the two basic options available to counterinsurgents attempting to replace rebel legitimacy with their own - either the cooption of local legitimacy 
from the ground up or its displacement from the bottom down - are likely to fail. Attempts to coopt local elites and their own legitimacy have proven unstable, while attempts to supplant them entirely from the top-down have failed. ${ }^{40}$ In countries with weak states which have never been seen as legitimate actors in many localities, the very idea of the state being recognized as such is a Eurocentric import. Research into rebel governance and legitimacy hence give us reasons to doubt whether FM 3-24's approach will work in any but the most permissive of circumstances.

Finally, both Western and authoritarian counterinsurgents need to rethink the relationship between means and ends in establishing legitimacy. Western counterinsurgency theorists focus on avoiding further delegitimizing the incumbent state through avoiding actions that harm the population, while attempting to improve its product on the market for governance. Yet given the culturally-bounded and locally oriented nature of legitimacy dynamics, the simple protection of the population is not enough to legitimize a state or to undermine activist rebel groups. The central insight of population-centric counterinsurgency is hence a sine qua non, but by no means a guarantor of success, which depends instead much more on factors beyond the counterinsurgents' control. Authoritarian counterinsurgents face the same problem when they rely on violence to put pressure on insurgents and change the nature of their relationship with the civilian population. While they help undermine the legitimacy of the rebels, they do little to improve that of the state.

Taken together, these critiques cast serious doubt on the Western counterinsurgency approach exemplified in FM 3-24 and its derivatives. For as long as legitimacy and legitimation remain under-theorized, over-generalized, and misunderstood, counterinsurgents will remain ineffectual at achieving their goals. It is hence urgent that practitioners and proponents of the 'graduate school of war' study these phenomena to give them a more realistic appreciation of the relationship of means to ends in the struggle for legitimacy. In turn, scholars of rebel governance and legitimacy have a vital role to play in illustrating the limits of counterinsurgency and the flaws in current doctrine and theory.

\section{Notes}

1. Department of the Army, J-P 1, Doctrine for the Armed Forces of the United States, $X$ (Italics added).

2. Department of the Army, FM 3-24 MCWP 3-33.5 Insurgencies and Countering Insurgencies, 1-27, 1-25.

3. For instance, see North Atlantic Treaty Organization "AJP-3.4.4: Allied Joint Doctrine for Counterinsurgency" (2011); and Ministry of Defense (UK), "JDP 3-40: Security and Stabilisation," 2-18-2-20 (2009).

4. Department of the Army, FM 3-24, 1-31, 5-8.

5. Galula, Counterinsurgency Warfare, 5 .

6. Trinquier, Modern Warfare. 
7. Galula, Counterinsurgency Warfare, 10,11 . He does add that it is '[s]o much the better' if 'popularity and effectiveness are combined', 11.

8. Cromartie, "Field Manual 3-24," 107.

9. On the Manual's constructivism, see Kalyvas, "Review of the New U.S. Army," 351-353.

10. Byman, "Death Solves All Problems"; and Ucko, "The People are Revolting."

11. Merom, How Democracies Lose Small Wars, 15.

12. Ucko, "The People are Revolting," 31, 35.

13. Arendt, The Human Condition, 201.

14. Schlichte and Schneckener, "Armed Groups and the Politics of Legitimacy," 413.

15. Arjona, "Wartime Institutions," 1363. See also Kalyvas, Logic of Violence in Civil War, 88.

16. See Daddis, No Sure Victory.

17. Department of the Army, FM 3-24, 1-29.

18. Dahl, Modern Political Analysis, 52.

19. Arjona, "Wartime Institutions"; Lyall, "Does Indiscriminate Violence Incite Insurgent Attacks?"; and Kalyvas, Logic of Violence in Civil War.

20. Department of the Army, FM 3-24, 1-27.

21. Scott, Seeing Like a State.

22. Department of the Army, FM 3-24, 1-28.

23. Jansen, "The Formation of German Nationalism," 234-259.

24. Tilly, Coercion, Capital, and European States; and Weber, Peasants into Frenchmen.

25. Scott, Weapons of the Weak; and Scott, Domination and the Arts of Resistance.

26. Quoted in Milne, "Our Equivalent of Guerrilla Warfare," 202.

27. Weinstein, Inside Rebellion.

28. Sukanya, "Mainstreaming the Non-state," 221.

29. Department of the Army, FM 3-24, 1-83. On this point, see Cromartie, "Field Manual 3-24."

30. Valentino, Huth, and Balch-Lindsay, "Draining the Sea."

31. Arjona, Kasfir, and Mampilly, “Conclusion," 294.

32. Scott, The Art of not Being Governed, 153.

33. Mampilly, "Performing the Nation-state."

34. Weinstein, Inside Rebellion, 9-11.

35. David Elliott's magisterial study of the NLF in Dinh Tuong province provides the best insight into this dynamic. See Elliott, The Vietnamese War.

36. Fitzsimmons, "Hard Hearts and Open Minds?" 337-365.

37. Arjona, "Wartime Institutions."

38. Kalyvas, "Rebel Governance during the Greek Civil War."

39. On this idea, see Metz, "Rethinking Insurgency," 35, 36.

40. Greene, "Pathological Counterinsurgency."

\section{Disclosure statement}

No potential conflict of interest was reported by the author.

\section{Bibliography}

Arjona, Ana. "Wartime Institutions: A Research Agenda." Journal of Conflict Resolution 58, no. 8 (2014): 360-389. 
Arjona, Ana, Nelson Kasfir, and Zachariah Mampilly. "Conclusion." In Rebel Governance in Civil War, edited by Ana Arjona, Nelson Kasfir, and Zachariah Mampilly, 286-300. Cambridge: Cambridge University Press.

Byman, Daniel."'Death Solves All Problems': The Authoritarian Model of Counterinsurgency." Journal of Strategic Studies 39, no. 1 (2016): 62-93.

Cromartie, Alan. "Field Manual 3-24 and the Heritage of Counterinsurgency Theory." Millennium 41, no. 1 (2012): 91-111.

Daddis, Gregory A. No Sure Victory. Oxford: Oxford University Press, 2011.

Dahl, Robert. Modern Political Analysis. 5th ed. Englewood Cliffs, NJ: Prentice Hall, 1991.

Department of the Army. FM 3-24 MCWP 3-33.5 Insurgencies and Countering Insurgencies. Headquarters, Department of the Army, May 2014, 1-27, 1-25. https://fas.org/irp/ doddir/army/fm3-24.pdf.

Department of the Army, J-P 1. Doctrine for the Armed Forces of the United States. Department of the Army, March 2013, x. http://www.dtic.mil/doctrine/new_pubs/ jp1.pdf.

Elliott, David W. P. The Vietnamese War: Revolution and Social Change in the Mekong Delta. Vol. 1 and 2. London: Sharpe, 2003.

Fitzsimmons, Michael. "Hard Hearts and Open Minds? Governance, Identity and the Intellectual Foundations of Counterinsurgency Strategy." Journal of Strategic Studies 31, no. 3 (2008): 337-365. doi:10.1080/01402390802024692.

Galula, David. Counterinsurgency Warfare: Theory and Practice. New York: Praeger, 1964.

Greene, Samuel R. "Pathological Counterinsurgency: The Failure of Imposing Legitimacy in El Salvador, Afghanistan, and Iraq." Third World Quarterly 38, no. 3 (2017): 563-579. doi:10.1080/01436597.2016.1205439.

Arendt, Hannah. The Human Condition. Chicago, IL: University of Chicago Press, 1958.

Jansen, Christian. "The Formation of German Nationalism, 1740-1850." In The Oxford Handbook of Modern German History, edited by Helmut Walser Smith, 234-259. Oxford: Oxford University Press, 2011.

Kalyvas, S. N. The Logic of Violence in Civil War. Cambridge: Cambridge University Press, 2006.

Kalyvas, S. N. "Rebel Governance during the Greek Civil War, 1942 - 1949." In Rebel Governance in Civil War, edited by Ana Arjona, Nelson Kasfir, and Zachariah Mampilly, 98-118. Cambridge: Cambridge University Press, 2015.

Kalyvas, S. N. "Review of the New U.S. Army/Marine Corps Counterinsurgency Field Manual in Political Science and Political Praxis." Perspectives on Politics 6, no. 2 (2008): 347-350. doi:10.1017/S1537592708081176.

Lyall, Jason. "Does Indiscriminate Violence Incite Insurgent Attacks?" Journal of Conflict Resolution 53, no. 3 (2009): 331-362.

Mampilly, Zachariah. "Performing the Nation-State: Rebel Governance and Symbolic Processes." In Rebel Governance in Civil War, edited by Ana Arjona, Nelson Kasfir, and Zachariah Mampilly, 74-97. Cambridge: Cambridge University Press.

Merom, Gil. How Democracies Lose Small Wars. Cambridge: Cambridge University Press, 2003.

Metz, Steven. "Rethinking Insurgency." In The Routledge Handbook of Insurgency and Counterinsurgency, edited by Paul B. Rich and Isabelle Duyvesteyn, 36. New York: Routledge, 2012.

Milne, David. "'Our Equivalent of Guerrilla Warfare': Walt Rostow and the Bombing of North Vietnam, 1961-1968." The Journal of Military History 71, no. 1 (2007): 169-203.

Ministry of Defence (UK), JDP 3-40. "Joint Doctrine Publication 3-40 Security and Stabilisation: The Military Contribution." Ministry of Defence. 2009. https://www.gov. 
uk/government/uploads/system/uploads/attachment_data/file/572959/archive_ doctrine_uk_jdp_3_40_a4.pdf.

North Atlantic Treaty Organization. "AJP-3.4.4: Allied Joint Doctrine for Counterinsurgency, 0109, 0110 (NATO)." NATO. 2011. https://info.publicintelligence.net/NATOCounterinsurgency.pdf.

Podder, Sukanya. "Mainstreaming the Non-state in Bottom-up State-building: Linkages between Rebel Governance and Post-conflict Legitimacy." Conflict, Security \& Development 14, no. 2 (2014): 213-243.

Schlichte, Klaus, and Ulrich Schneckener. "Armed Groups and the Politics of Legitimacy." Civil Wars 17, no. 4 (2015): 409-424. doi:10.1080/13698249.2015.1115573.

Scott, James C. Weapons of the Weak: Everyday Forms of Peasant Resistance. New Haven, CT: Yale University Press, 1985.

Scott, James C. Domination and the Arts of Resistance: Hidden Transcripts. New Haven, CT: Yale University Press, 1990.

Scott, James C. Seeing like a State: How Certain Schemes to Improve the Human Condition Have Failed. New Haven, CT: Yale University Press, 1998.

Scott, James C. The Art of Not Being Governed: An Anarchist History of Upland Southeast Asia. New Haven, CT: Yale University Press, 2009.

Tilly, Charles. Coercion, Capital, and European States: A.D. 990 - 1992. Malden, MA: WileyBlackwell, 1993.

Trinquier, Roger. Modern Warfare: A French View of Counterinsurgency. Translated by Daniel Lee. New York: Praeger, 1964.

Ucko, David H. "'The People Are Revolting': An Anatomy of Authoritarian Counterinsurgency." Journal of Strategic Studies 39, no. 1 (2016): 129-161.

Valentino, Benjamin, Paul Huth, and Dylan Balch-Lindsay. "'Draining the Sea': Mass Killing and Guerrilla Warfare." International Organization 58, no. 2 (2004): 375-407.

Weber, Eugen. Peasants into Frenchmen: The Modernization of Rural France, 1870-1914. Palo Alto, CA: Stanford University Press, 1976.

Weinstein, Jeremy. Inside Rebellion: The Politics of Insurgent Violence. Cambridge: Cambridge University Press, 2009. 